\title{
Using Computer-assisted Language Learning in Classrooms: What Does Research Say about Teachers' Beliefs and Practices?
}

\author{
Zainab Alsuhaibani \\ Imam Mohammad Ibn Saud Islamic University, Saudi Arabia
}

\begin{abstract}
The last decades have witnessed the introduction of Information and Communication Technologies (ICTs) into the field of education. This introduction has brought in major changes in the traditional view of language teaching and learning. Accordingly, the implementation of technology through Computer-Assisted Language Learning (CALL) and its success has become of particular interest. However, the success of CALL implementation does not merely depend only on economic investments. In fact, teachers play a major role in using technology successfully in classrooms (Galvis, 2012). Thus, it is important to investigate teachers' beliefs about CALL implementation and see whether they practically practice their beliefs in classrooms. Of equal importance is to investigate and question why some teachers do not practice their beliefs. This paper attempts to shed light on teachers' beliefs and practices of CALL implementation in classrooms. First, teachers' beliefs are defined and their importance and formation process are presented. Then, teachers' beliefs about CALL implementation in language classrooms are discussed along with the factors that affect them. A discussion of whether teachers' beliefs about technology entail their actual practice is then provided. Finally, barriers hindering teaches' practices of technology in language classrooms are explained.
\end{abstract}

Index Terms —CALL, teachers' beliefs, practices, pedagogy, technology

\section{TEACHERS' BELIEFS: Definition AND Formation}

Beliefs have an influential effect in many educational areas (Borg, 2003). Generally, beliefs are often described as both valuable and difficult construct to define because they do not lend themselves to empirical investigations (Pajares, 1992). However, several definitions have been proposed for beliefs. Richardson (1996) defined beliefs as ideas and conceptions that a person either consciously or unconsciously perceives to be true. Pajares (1992) also defined beliefs as an "individual's judgment of truth or falsity of a proposition, a judgment that can only be inferred from a collective understanding of what human beings say, intend, and do" (p.316). Commonly, different terms are usually used to refer to beliefs such as attitudes, perceptions, implicit theories, perspectives, opinions and judgments (Pajares, 1992). Clark and Peterson (1986) described teachers' beliefs as the core of knowledge that influences teachers' pedagogical planning and their instructional decisions. Elen and Lowyck (1999) defined teachers' beliefs as suppositions about educational issues such as teaching, learning, and curricula. Teachers' beliefs are manifested in their personal philosophies of education and include their beliefs of various strategies for creating learning environments and conducting lessons, and more fundamentally beliefs about learners, how they learn, and how that learning can be fostered by teaching (Borko \& Putnam, 1995). With regard to language instruction, Richards and Rodgers (2001) asserted that teachers have certain beliefs about language and language learning which provide them with a teaching philosophy for a adopting a specific approach in language instruction. Additionally, Connelly and Clandinin (1988) stated that teachers' beliefs reflect their perceptions of curriculum implementation including the roles they assume, the roles they assign to their students, and the methods and approaches of teaching the content of the curriculum in the actual learning setting. Thus, teachers' beliefs don't influence their goals only, but they affect their procedures, materials, classroom interaction patterns, their roles, their students, and the schools they work in, as well (Harste and Burke, 1977). They have a great impact not only on the depth and breadth of their teaching craft, but also on what students learn, how they learn, and how teachers approach teaching and learning (Palak, 2004).

Mainly, teachers' beliefs are formed by different sources. Richardson (1996) suggested three types of experiences that shape and form beliefs of teaching. These experiences include personal experience, experience with schooling and instruction, and experience with formal knowledge. Similarly, Erkmen (2010) stated that the sources of teachers' beliefs which have been identified in research include teachers' personal experiences as students, and teacher education. Also, Orton (1996) considered teacher beliefs to be context bound and situational. He maintained that teachers' beliefs are not rooted in theories of learning or teaching or theories of cognition, but in the past situations, particular instances, and trial and error experiences. 
Whether or not a teacher will implement new teaching strategies and technological innovations or support educational reforms largely depends on his or her beliefs (Clark \& Peterson, 1986). Teachers' beliefs are regarded as a key predictor of using technological innovations in the educational context (Albirini, 2006). In fact, teachers' beliefs about CALL play an important role in their acceptance and integration of technology as well as the way they successfully use technology in their classrooms (Al-Zaidiyeen, Mei, \& Fook , 2010). Kim (2002) argued that teacher' beliefs about CALL can be considered as a facilitating or inhibiting factor. They can facilitate the use of technology as they give teachers more confidence in using it. On the other hand, teachers' beliefs may act as a barrier to using CALL. In the same vein, Gilakjani and Leong (2012) stated that if any success is to be expected from integrating technology into the classroom, it is a must that negative teachers' beliefs are identified and refined as well as positive beliefs are fostered. In fact, the literature on teachers' beliefs yielded different results. Most of the studies showed positive teachers' beliefs about integrating technology in language classrooms. Still others showed that teachers have negative beliefs about technology.

Most studies from different parts of the world indicate that teachers have positive beliefs about using CALL in language classroom (Cummings, 2005; Albirini, 2006; Akcaoglu, 2008; Alshumaimeri, 2008; Park \& Son, 2009; AlZaidiyeen, Mei, \& Fook , 2010; Emhamed \& Krishnan, 2011; Genc, 2011; Cahyani \& Cahyono,2012; Capan, 2012; Dashtestani, 2012; Başöz, \& Çubukçu, 2013; Baz,2016; İnce,2017; Soylemez, \& Akayoglu, 2019). Emhamed and Krishnan (2011) found that most of the Libyan teachers had positive attitudes toward integrating technology in teaching EFL students. Teachers believed that technology fosters students' learning as it makes learning enjoyable and interesting. It also helps them as teachers to become facilitators, and it assists them in integrating language skills (reading, writing, speaking and listening) rather than teaching these skills separately. Also, the teachers in Dashtestani's study (2012) perceived the use of CALL as a beneficial tool for enhancing students' motivation, autonomy, selfconfidence, and learning multi-cultural competence. In addition, they view it as an important, facilitative and interactive tool in EFL teaching. They maintained that CALL facilitates the accessibility to information, professional development, use of different instructional approaches, and EFL assessment and evaluation. Likewise, in Park and Son's (2009) study, all teachers regarded the use of CALL in classrooms as essential and desirable as it creates an attractive environment for the students in the ICT world. They believed that the use of technology adds value to their teaching, improves their pedagogical approaches, and provides them with rich information resources and authentic materials along with different ways of presentation. They also considered CALL as a helpful means for language practice asserting that it can make the process of language learning easier and faster.

In spite of these positive beliefs about technology, teachers are still more inclined to hold teacher-centered rather than student-centered beliefs about teaching and learning. The teachers in Park and Son's (2009) study indicated that using CALL cannot fully guarantee better quality of education. They believed that the quality of education depends mainly on the quality of teachers, not on the use of technologies. They argued that what ensures effective language instruction is their positive stance and constant efforts to introduce new technologies and teaching materials to their classrooms. They also asserted that they should play dominant roles and be fully responsible for controlling students' progress and activities. In the same vein, the teachers in Akcaoglu's study (2008) indicated that technology would help make their classes more student-centered. However, they mainly mentioned using technology as a teacher tool rather than as a student tool which help foster learners' autonomy and higher order thinking skills. Kim (2008) also found that teachers' perceptions of CALL showed a strong preference for teacher-centered approach. They restricted the role of CALL to a supplemental instructional tool. They basically viewed the role of computer as an optional tool for tutoring, communication, presentation and writing, and as a motivator. These common teachers' perceptions indicated that their expectations of computers are limited to considering them as an instructional tool, not as a learning tool for students. Kim commented that although current language instructional approaches changed from teacher-centered to studentcentered, teachers' beliefs of computers have not yet changed.

However, not all teachers have positive beliefs about integrating technology into their language classrooms. Some teachers don't support using technology in classrooms, while others actually resist its use. Such reluctance or even resistance to use technology in classrooms might be due to doubts and low confidence. Teachers feel more secured and confident when they practice traditional instruction (Gilakjani \& Leong, 2012). Hismanoglu (2012) conducted a study on pre-service teachers' perceptions about using CALL in teaching English as a foreign language of the distance higher education system in Turkey. The results indicated that the teachers had negative attitudes toward CALL. They felt less competent in using technology due to lack of knowledge and experience.

Nevertheless, studies that report negative beliefs are few compared to studies indicating positive teachers' beliefs about technology integration in language classroom. Actually, differences in teachers' beliefs are related to certain factors that affect them.

\section{FACTORS AfFecting LANGUAge TEACHERS' Beliefs ABOUT CALL}

Studies report several factors that affect teachers' beliefs about CALL integration in language classrooms, including technological competence and personal experience (Albirini, 2006; Park and son, 2009; Capan, 2012), cultural perceptions (Albirini, 2006; Capan, 2012), age (Albirini, 2004; Akcaoglu, 2008), years of experience in teaching (Tezci, 2009), and the institution and work place (Akcaoglu, 2008; Suwannasom, 2010). 
With regard to technological competence and cultural perceptions, Albirini (2006) found that EFL teachers of high school had positive beliefs about using technology in Syrian education. Those beliefs were formed by their vision of technology, their experiences with it and the cultural conditions which surround them. Likewise, Capan's study (2012) suggested that there are important factors affecting EFL teachers' beliefs towards using technology in classrooms. Among these factors are high computer competence, positive cultural perceptions and access to computers at home and in school .With this regard, Park and Son (2009) commented that language teachers can have the confidence to integrate CALL in their teaching if they have different positive teaching and learning experiences besides positive cultural perceptions about using computers. Through these learning and teaching experiences, teachers become certain that technology can affect students' motivation positively with its desirable environment. They also recognize the Internet as a rich source of information and as a means for providing valuable opportunities to experience the foreign culture. At the same time, they feel comfortable and confident in their implementation since they do not violate cultural perceptions. Concerning age, Akcaoglu (2008) found out that the younger teachers had higher competence and more positive attitudes toward computers. On the other hand, older teachers had more negative attitudes toward technology. They also had lower competence in using computers. Accordingly, Akcaoglu pointed out that such different attitudes between younger and older teachers reflect the inclination in the society toward technology. Since the new generation grows up using innovational technology, they are able to use it easily and comfortably. Another factor that is somewhat related to age is years of experience in teaching. Tezci (2009) found that teachers with fewer years of experience in teaching have more positive attitudes toward technology use. Moreover, institutional support of technology resources is a substantial factor affecting teachers' beliefs. The study of Akcaoglu (2008) revealed that teachers at universities which are supported with technological facilities for language teaching purposes had the highest attitude level, and the highest usage, as well. The use of computers by those teachers in their lessons helped them improve their computer skills and foster their positive beliefs and thus, they advance their peers who potentially graduated from the same universities and had the same ICT training.

\section{Do Teachers' Positive Beliefs about CALL Entail Practice?}

Teachers' beliefs greatly influence their instructional practice (Farrell \& Lim, 2005). In fact, some research shows that it is a teacher's belief system that has the greatest impact on instructional practice (Lam \& Kember, 2006). Liaw (2002) maintained that the success of computer use heavily depends on positive beliefs about it. Similarly, Kim (2002) emphasized that teachers' beliefs significantly influence their use of computers in the classroom. Al-Zaidiyeen, Mei,and Fook (2010) went further and asserted that teachers beliefs do not only affect teachers' integration of technology in language classrooms but they also affect the frequency and the amount of the use of technology.

In fact, studies indicate that a significantly positive correlation holds between teachers' beliefs about computers and their tendency to use them in the classroom. In other words, the more positive attitudes teachers have about computers, the more likely they are to use computers in the classroom (Al-Zaidiyeen, Mei, \& Fook , 2010; Capan, 2012). Park and Son (2009) stated that the teachers in their study believed in utilizing computer technologies in language classrooms. They believed that they are helpful for enhancing students' language learning. Practically, teachers used Word Processing, PowerPoint, the Internet and CD-ROMs in the classroom. Among these tools, they regarded the Internet and CD-ROMs as the most helpful teaching tools. Also, Genc (2011) found that teachers have positive attitudes toward the integration of computer technology with instruction. Their positive attitudes are reflected in their use of different computer applications and programs such as word processing, PowerPoint, Internet and educational software.

However, sometimes, teachers' positive beliefs about CALL do not entail actual practice of these beliefs. Egbert, Paulus and Nakamichi (2002) argued that positive attitudes toward CALL do not assure that teachers will actually use it in their classrooms. Dashtestani (2012), in his study, declared that in spite of their positive beliefs, most of EFL teachers do not use technology in their classes. The EFL teachers' common use of technology was confined to playing some mp3 audio tracks. Such audio activities are actually based on the textbook activities used for developing learners' listening skill. The printed textbooks were the main teaching materials used by EFL teachers and students. Additionally, Kim (2002) found that although all participants in her study had positive attitudes and strong intrinsic motivation toward the use of technology in classrooms, teachers' actual use of technology was limited, frequently delayed, avoided or withdrawn. Likewise, Akcaoglu (2008) found that despite reporting positive beliefs about CALL, teachers used computers in their classrooms at limited frequency.

From the studies reviewed above, it is clear that positive beliefs do not necessarily entail practice. Some teachers do practice their beliefs and implement technology in their language classrooms. Others, however, do not practice the positive beliefs they hold about technology. These findings lead to question why some teachers do not practice technology in their language classrooms if they really have positive beliefs about it. In reality, the inconsistency between the reported positive beliefs and low technology implementation in language classrooms can be attributed to different constraints and barriers that prevent teachers from implementing technology in their classes.

\section{BARRIERS HINDERING CALL IMPLEMENTATION IN CLASSROOMS}


The studies reviewed in this paper as well as the literature of teachers' beliefs and practices identified several barriers that hinder the implementation of CALL in language classrooms. These barriers can be classified into: lack of technological facilities (Lee \& Son, 2006; Akcaoglu, 2008; Park \& Son, 2009; Dashtestani, 2012), lack of knowledge and training (Chen, 2007; Akcaoglu, 2008; Cahyani \& Cahyono,2012; Dashtestani, 2012, Aydin, 2013), curricular limitations (Ertmer, 2005; Albirini, 2006; Akcaoglu, 2008; Park \& Son, 2009; Suwannasom, 2010), lack of time (Albirini, 2006; Park \& Son, 2009; Suwannasom, 2010; Emhamed\& Krishnan, 2011), and financial barriers (Lee, 2000; White, 2006;Emhamed\& Krishnan, 2011; Dashtestani, 2012).

\section{A. Lack of Technological Facilities}

Unfortunately, not all language classes are equipped with technological tools, and some are actually old and need maintenance. Moreover, the types of software suitable for EFL courses are not easily available to EFL teachers (Dashtestani, 2012). Internet connection problems also discourage teachers to use computers (Park and Son, 2009). Also, inconvenience encountered in the use of computer labs hinders teachers' willingness to use CALL (Lee and Son, 2006). Generally, the lack of network, computers, and availability of computer hardware and software hinders teachers' potential to use computers during their instruction. Thus, the infrastructure stands in the way of teachers who have positive beliefs about technology and are actually willing to use it (Akcaoglu, 2008).

\section{B. Lack of Knowledge and Training}

Some EFL/ESL teachers don't use technology effectively because they lack training on how to use it in language classes and how to deliver their teaching using new technological innovations appropriately (Cahyani \& Cahyono, 2012). In his study, Alshumaimeri (2008) found positive correlation between training and positive attitudes towards the use of technology which indicate that training helps teachers to be more confident in using CALL. Dashtestani (2012) maintained that some teachers do not have sufficient knowledge to use CALL in their EFL classes. The current knowledge of CALL they have is gained from their experience and not from teacher training courses. More specifically, teachers are not sure about the skills they need, which technological tools they should use, and what course syllabus is suitable for teaching with the technology (Chen, 2007). In fact, teachers indicate that apart from access to computers, lack of training opportunities and knowledge about the proper use of computers and the internet in language learning constitute a major barrier to their technology integration (Akcaoglu, 2008).

\section{Curricular Limitations}

Among the challenges that teachers encounter in trying to implement technology into their classrooms is the difficulty to adjust or find appropriate and suitable technological tools for their curriculum (Ertmer, 2005). Inflexible curricula hinder teachers from integrating technology as they don't allow for modifications or adjustment. In addition, teachers have specific content and test schedules to follow, thus, they find it difficult to add technology-related activities into the predefined course plan (Suwannasom, 2010). In Akcaoglu's study (2008) teachers mentioned that the curriculum they are following is a barrier to their usage of computers in classroom. Proficiency exams and rigid course books make them helpless in terms of technology integration.

\section{Lack of Time}

Limited time is one of the most reported barriers that affect teachers' use of technology in the classroom. Using technology in the classroom constitute an extra burden on teachers because new technology skills require additional time for learning and training. In addition, integrating technological activities in class lessons need a lot of preparation time (Suwannasom, 2010). Looking for suitable on-line materials that meet students' proficiency levels and needs is time-consuming for teachers (Park \&Son, 2009). In addition, the class time itself is not enough for the implementation of technology in the classrooms (Emhamed\& Krishnan, 2011).

\section{E. Financial Barriers}

Financial barriers include the cost of hardware, software, and maintenance. They also include staff training cost (Lee, 2000). Most CALL-based facilities are too expensive to be bought by teachers themselves (Dashtestani, 2012). In fact, institutions and teachers alike have difficulties affording the cost of equipment or software applications to implement CALL effectively in their language classes (White, 2006).

\section{CONCLUSION}

Taking into account that research on teachers' beliefs and practices is still in its infancy, the results of the studies reviewed in this paper are promising. They indicate that most teachers have positive beliefs' about CALL, and that some teachers are actually implementing it in language classrooms despite having some barriers and constraints. However, practically speaking, implementing technology in language classrooms is not an easy task; it is not only about implementing technology. Teachers need to be trained in how to implement technology effectively following a learnercentered rather than a teacher-centered approach. They need to be guided to use technology as a learner tool in which the students are viewed as active learners who are responsible for their learning. In fact, research is needed on how to 
redefine the role of the teacher in CALL classrooms. Also, exploring change in teachers' beliefs toward technology and CALL and how such change affects their practices is an area that needs researchers' attention.

\section{REFERENCES}

[1] Akcaoglu, M. (2008). Exploring technology integration approaches and practices of pre-service and in-service English language teachers. Unpublished Master Thesis. Middle East Technical University, Ankara.

[2] Albirini, A. (2006). Teachers' attitudes toward information and communication technologies: The case of Syrian EFL teachers. Computers \& Education, (47), 373-398.

[3] Alshumaimeri, Y. A. (2008). Perceptions and attitudes toward using CALL in English classrooms among Saudi secondary EFL teachers. The JALT Call Journal, 44(2), 29-66.

[4] Al-Zaidiyeen, N.J., Mei, L.L. \& Fook, F.S. (2010). Teachers' attitudes and levels of technology use in classrooms: the case of Jordan. International Education Studies 3(2), 211-218.

[5] Aydin, S. (2013). Teachers' perceptions about the use of computers in EFL teaching and learning: the case of Turkey. Computer Assisted Language Learning, 26(3), 214-233, DOI: 10.1080/09588221.2012.654495.

[6] Başöz, T., \& Çubukçu, F. (2013). Pre-service EFL teacher's attitudes towards computer assisted language learning (CALL). Procedia-Social and Behavioral Sciences, 116, 531-535

[7] Baz, E. H. (2016). Attitudes of Turkish EFL Student Teachers towards Technology Use. Turkish Online Journal of Educational Technology-TOJET, 15(2), 1-10.

[8] Borg, S. (2003). Teacher cognition in language teaching: A review of research on what language teachers think, know, believe, and do. Language Teaching, 36(2), 81-109.

[9] Borko, H., \& Putnam, R. (1995). Expanding a teachers' knowledge base: A cognitive psychological perspective on professional development. In T. Guskey \& M. Huberman (Eds.), Professional development in education: New paradigms and practices (pp. 35-65). New York: Teachers College Press.

[10] Cahyani,H. \& Cahyono, B. (2012). Teachers; attitudes and technology use in Indonesian EFL classrooms. TEFLIN Journal, 2 (23), 130-148.

[11] Capan, S.A. (2012). Teacher Attitudes towards Computer Use in EFL Classrooms. Frontiers of Language and Teaching, 3 , 248-254.

[12] Chen, K.(2007) The implementation of educational technology on the teaching of Chinese as a foreign language. Ming Dao Journal of General Education, 2, 179-202.

[13] Clark, C. M., \& Peterson, P. L. (1986). Teachers' thought processes. In M. C. Wittrock (Ed.), Handbook of research on teaching (3rd ed.). New York: Macmillan.

[14] Connelly, F. M., \& Clandinin, D. J. (1988). Teachers as curriculum planners: Narratives of experience. New York: Teachers College Press.

[15] Cummings, A. (2005). Administrative and pedagogical uses of computers in foreign language classrooms: A survey of Spanish teachers' beliefs and practices. (Doctoral dissertation). University of Iowa, Iowa.

[16] Dashtestani, R. (2012). Barriers to the implementation of CALL in EFL courses: Iranian EFL teachers' attitudes and perspectives. Jaltcall Journal, 2(8), 55-70.

[17] Deniz, L. (2007). Prospective class teachers' computer experiences and computer attitudes. International Journal of Human and Social Sciences, 2(2), 116-122.

[18] Egbert, J., Paulus, T. M. \& Nakamichi, Y. (2002). The impact of CALL instruction on classroom computer use: A foundation for rethinking technology in teacher education. Language Learning \& Technology, 6(3), 108-126.

[19] Elen, J., \& Lowyck, J. (1999). Metacognitive instructional knowledge: Cognitive mediation and instructional design. Journal of Structural Learning and Intelligent Systems, 13, 145-169.

[20] Emhamed, .E \& Krishnan, S. (2011). Investigating Libyan teachers' attitude towards integrating technology in teaching English in Sebha secondary schools. Academic Research International, 1 (3),182-192.

[21] Erkmen, B. (2010). Non-Native Novice EFL Teachers' Beliefs about Teaching and Learning. (Doctoral dissertation). University of Nottingham, UK.

[22] Ertmer, P. A. (2005). Teacher pedagogical beliefs: The final frontier in our quest for technology integration? Educational Technology Research and Development, 53(4), 25-39.

[23] Farrell, T, S, C, and Lim P. (2005). Conceptions of grammar teaching: A study of teachers' beliefs and classroom practices. TESL-EJ, 9(2), 1-13.

[24] Galvis, H. (2012). Understanding beliefs, teachers' beliefs and their impact on the use of computer technology. 2(14), 2, 95-112.

[25] Genc, H. (2011, March). Investigating In-service EFL Teachers' attitudes towards integrating ICTs into Instruction. In Society for Information Technology \& Teacher Education International Conference (pp. 2465-2472). Association for the Advancement of Computing in Education (AACE).

[26] Gilakjani, A. P. \& Leong, L.-M. (2012). EFL teachers' attitudes toward using computer technology in English language teaching. Theory and Practice in Language Studies, 2(3), 630-636.

[27] Harste, J. C., \& Burke, C. L. (1977). A new hypothesis for reading teacher research: Both the teaching and learning of reading is theoretically based. In P. D. Pearson (Ed.), Reading: Theory, research and practice (pp. 32-40).New York: National Reading Conference.

[28] Hismanoglu, M. (2012). Prospective EFL teachers' perceptions of ICT integration: A study of distance higher education in Turkey. Educational Technology \& Society, 15(1): 185-196.

[29] İnce, M. N. (2017). The analysis of EFL teachers' perceptions of CALL and variables influential on teachers' attitudes. Journal of Narrative and Language Studies, 5(8), 59-72.

[30] Kim, H. (2002). Teachers as a barrier to technology-integrated language teaching. English Teaching, 57(2), 35-64. 
[31] Kim, H. (2008). Beyond motivation: ESL/EFL teachers' perceptions of the role of computers. CALICO Journal, 25 (2), 241 259.

[32] Lam, Y. (2000). Technophilia vs. technophobia: A preliminary look at why second -language teachers do or do not use technology in their classrooms. Canadian Modern Language Review, 15(3), 295-315.

[33] Lam, B., \& Kember, D. (2006). The relationship between conceptions of teaching and approaches to teaching. Teachers and Teaching: theory and practice, 12, 693-713.

[34] Lee, K. (2000). English teachers' barriers to the use of computer-assisted language learning. The Internet TESL Journal, 6(12).

[35] Lee, S., \& Son, J.-M. (2006). The use of ICT in Korean middle school English classrooms: Practices and challenges. English Language Teaching, 18(1), 49-73.

[36] Liaw, S. S. (2002). Understanding user perceptions of world-wide web environments. Journal of Computer Assisted Learning, 18(2), 137-148.

[37] Orton, R. E. (1996). How can teacher beliefs about student learning be justified? Curriculum Inquiry, 26(2), $133-146$.

[38] Pajares, M. F. (1992). Teachers' beliefs and educational research: cleaning up a messy construct. Review of Educational Research, 62(3), 307-332.

[39] Palak, D. (2004). Teachers' beliefs in relation to their instructional technology practices. (Unpublished doctoral dissertation). West Virginia University

[40] Park, C. N. \& Son, J.-B. (2009). Implementing computer-assisted language learning in the EFL classroom: Teachers' perceptions and perspectives. International Journal of Pedagogies and Learning, 5(2), 80-101.

[41] Richardson, V. (1996). The role of attitudes and beliefs in learning to teach. In J. Sikula (eds.). The handbook of research in teacher education. New York: Macmillan, 102-119.

[42] Richards, J. C. and Rodgers, T. S. (2001). Approaches and methods in language teaching (2nd Ed.) New York: Cambridge University Press.

[43] Soylemez, A., \& Akayoglu, S. (2019). Prospective EFL Teachers' Perceptions of Using CALL in the Classroom. In Pre-Service and In-Service Teacher Education: Concepts, Methodologies, Tools, and Applications (pp. 1405-1418). IGI Global.

[44] Suwannasom, T. (2010). Teacher cognition about technology-mediated EFL instruction in the Thai tertiary context. (Doctoral dissertation). Massey University. New Zealand.

[45] Tezci, E. (2009). Teachers' effect on ICT use in education: The Turkey sample. Procedia Social and Behavioral Sciences, 1, 1285-1294.

[46] White, R. (2006). TEFL barriers and benefits of computer assisted language learning. Retrieved June 2018 from http://www.teflcorp.com/articles/90-tefl-call-computer-aided-language-learning/274-barriers-and-benefits-of-computerassisted-language-learning-or-call.htm.

Zainab Alsuhaibani is an assistant professor in Applied Linguistics at Imam Mohammad Ibn Saud Islamic University, Riyadh, Saudi Arabia. She gained her PhD with first degree of honor in 2016 from College of Languages and Translation at Imam Mohammad Ibn Saud Islamic University. Her research interest includes foreign language teaching and learning, second language acquisition, language learning strategies, pragmatic competence and pragmatic instruction, intercultural communication, corpora, CALL, and sociolinguistics. 